\title{
Estimates of the economic impacts of sea level rise on paros and naxos islands (cyclades archipelago greece)
}

\begin{abstract}
The effects of climate change are numerous and diverse, often interlinked, causing severe impacts on the economic and physical environment of the affected areas. Freshwater shortage and sea level rise are highlighted as the priority risks of climate change in Mediterranean coastal region. This study seeks to illustrate at a local level the impact that sea level rise may generate on the coastal communities of Cyclades Islands in Greece. After developing three different scenarios of sea level rise by $0.3,0.6$ and $1 \mathrm{~m}$ in tandem with the use of Geographic Information System (GIS) as a mapping tool the percentage of inundated area at different islands was illustrated and the respective economic cost was calculated. Results revealed that in the most possible case scenario of sea level rise by $0.6 \mathrm{~m}$ the total land loss value for the whole Cyclades complex reaches almost 4 billion $€(\sim 2.22$ of National GDP) with Naxos island being the most vulnerable. Further research needs to take into consideration additional factors related to the impact assessment of sea level rise in Cyclades in order to produce more robust results.
\end{abstract}

Keywords: Paros island, Naxos island, Cyclades, Sea level rise, Climate change, GIS
Volume 2 Issue 2 - 2015

\author{
Klaoudatos DS, Kokkali A, Conides A \\ Institute of Marine Biological Resources and Inland Waters, \\ Greece
}

Correspondence: Dimitris S Klaoudatos, Hellenic Centre for Marine Research, Institute of Marine Biological Resources, MavroLithari PO Box 712, 19013, Anavissos, Attica, Greece, Tel 00302109856717,Email dklaoudatos@hcmr.gr

Received: December 23, 2014 | Published: April 18, 2015
Abbreviations: GIS, Geographic Information Systems; WMO, World Meteorological Organization; UNEP, United Nations Programme for the Environment; IPCC, Intergovernmental Panel on Climate Change; CBA, Cost-Benefit Assessment

\section{Introduction}

Over the recent decades $\mathrm{CO}_{2}$ emissions have considerably increased due to the intense use of fossil fuels in industry resulting to global warming and global climate changes. The latest Reports of the World Meteorological Organization (WMO) and the United Nations Programme for the Environment (UNEP) indicate that between 1980 and 2005 the world ambient temperature had increased between 1 and $1.5^{\circ} \mathrm{C} .{ }^{1}$ One of the most critical issues arisen from the ongoing global warming is the expected sea level rise and thus focus has been put on the future sea level trends which inextricably affect coastal areas and islands. Global climate changes are expected to cause sea level rise and this way result in floods, coastal erosion, inundation of wetlands and other important coastal formations as well as other ecological and environmental losses with important economic results. ${ }^{2,3}$ The impact of climate change will also interact and multiply the negative effects of existing coastal stressors reducing the resiliency of the coastal systems from all points of view such as social, economic and environmental. ${ }^{2,4}$

Actual measurements have shown that during the $20^{\text {th }}$ century, the sea level has risen about $0.17 \pm 0.05 \mathrm{~m}^{5}$ based on IPCC reports. However, IPCC committee has not yet include in their models for forecasting sea level rise, the polar ice melting process due to the global increase in sea and air temperatures. Researchers ${ }^{6,7}$ proposed a significant acceleration of sea level rise in the $20^{\text {th }}$ century and estimated a sea level rise from 2.0 to 3.4 meters between 1990 and 2100 if the acceleration remains constant by including ice melting as a factor in their calculations. The implications of such a seal level rise scenario are enormous as nearly quarter of the world's population lives at elevations below $100 \mathrm{~m}$ from mean sea level and within 100 $\mathrm{km}$ from coasts. ${ }^{8,9}$ At the same time, these areas concentrate most of the human economic activities. ${ }^{10}$ The expected inundation of sea will probably disrupt the physical processes as well as the socio-economic systems along the coasts. Targeting to assist policy makers and general public in understanding the risks and expected results of sea level rise, both global and local studies are required to allow a holistic approach to the management of the issue. ${ }^{11}$

The assessment of the vulnerability of coastal resources to the impacts of sea level rise is delineated into both natural (natural system vulnerability) and socio-economic environment (socio-economic system vulnerability). The prerequisite of the socioeconomic vulnerability analysis relies on the efficient knowledge about natural response system to sea level rise. ${ }^{12}$ Adaptation to these phenomena is mainly translated into cost assessment rather than cost-benefit assessment (CBA) as decision makers are not for supporting "inaction" but making optimal actions that would ensure the safety of the area at risk. ${ }^{13}$ The rates of sea level change in Mediterranean are a controversial issue. Carillo et al. ${ }^{14}$ stated that the characteristics of Mediterranean Sea as a semi-closed basin connected to the Atlantic Ocean only through the Strait of Gibraltar allow for differing from the global sea level trends. Applying statistical techniques on satellite data ${ }^{15}$ estimated an increase of sea level trend about $0.63 \mathrm{~mm}$ year- 1 for the period 1993-2000 using tide gauge data whereas in another study by ${ }^{16}$ identified an increase at a rate of 1.2-1.5 mm year- 1 before 1960 and a decrease at a rate of $-1.3 \mathrm{~mm} /$ year between 1960 and 1998. $\mathrm{As}^{12}$ reported in Adriatic and Aegean Seas the raise of average temperature will be greater than in Levantine basin raising the elevation rate in the eastern part of Mediterranean basin at rate of +5 and $+15 \mathrm{~mm} / \mathrm{year}$ compared to less than $+5 \mathrm{~mm} /$ year in the western part. The Aegean Sea is considered to be the most exposed area of the Mediterranean Sea to sea level rise due to high water temperatures. ${ }^{17}$ The impacts of sea level rise will be particularly strong on the majority of the Mediterranean coastal areas as they housed $36 \%{ }^{18}$ of the EU coastal regions population in 2009 with a trend to increase by $1.4 \%$ in $2025^{19}$ 
causing floods land loss salinization of groundwater and destruction of built property and infrastructure..$^{20}$ Given the large and growing concentration of population and economic activity in the coastal zone as well as the importance of coastal ecosystems the potential impacts of sea-level change have evoked widespread concern for more than two decades. ${ }^{21-23}$

The present study focuses on Paros and Naxos Islands (belonging to the Cyclades Archipelago Greece). The main aim of this study was to assess and visualize the percentage of the inundation area after developing three different scenarios of sea level rise in the study area using GIS as a tool. The assessment will be elaborated after depicting the hotspots (areas of high risk in terms of social touristic and infrastructure value) and estimating the economic loss for each different scenario. Recent scenarios for $2100^{24,25}$ and sealevel measurements ${ }^{12}$ suggest an acceleration in sea-level rise. This enhances the importance of a new simulation of the impact of rising sea level on the shoreline position. Our objective was to quantify the role of sea-level rise in the shoreline retreat and evaluate this retreat in terms of future sea-level rise.

\section{Materials and methods}

\section{Study area}

Cyclades is a complex of islands located in the central Aegean Sea (Greece) and belongs to the South Aegean Region. The group consists of more than 150 islands from which 24 are inhabited (Figure 1). The population of Cyclades has increased from 94005 in 1991 to 112615 in 2001 and 117987 in 2011 (Hellenic National Statistical Survey annual reports) and the total surface is approximately 2528 $\mathrm{km}^{2}$. The natural environment of Cyclades is very rich as it hosts a great variety of ecosystems which although they have limited size they host significant ecological features and protected areas that are included in the NATURA 2000 Network. The main human activities taken place in Cyclades are agriculture mining fishing small-scaleindustry and tourism. Tourism has long played an important role in the economic development of Cyclades characterizing them as one of the most significant tourism destinations in Greece.

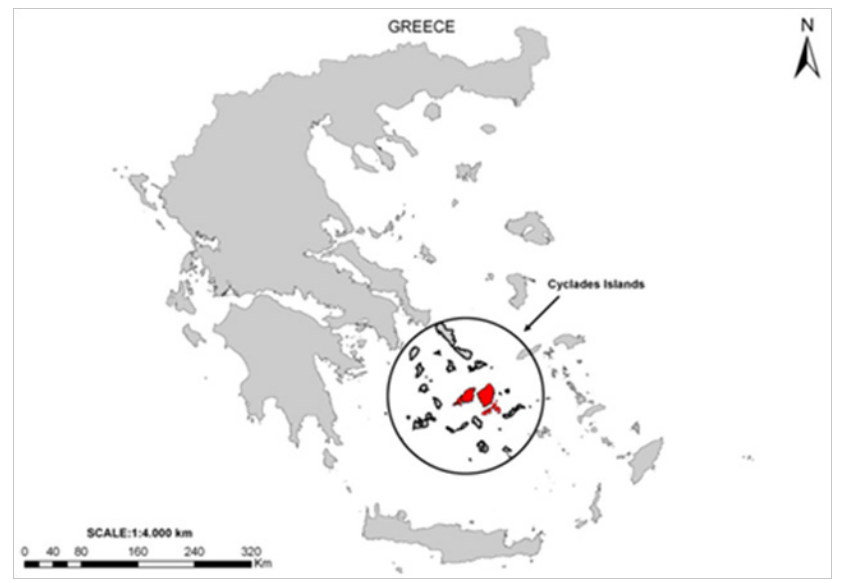

Figure I Map of the study area (with red the islands of Paros and Naxos).

Naxos Island is the largest island in Cyclades with an area of 429 $\mathrm{km}^{2}$ and a population 18200 and a density of 42 inhabitants $/ \mathrm{km}^{2}$. Paros Island is also one of the largest islands of the Cyclades complex with an area of $196.3 \mathrm{~km}^{2}$ a population of $6058^{26}$ and a density of 70 inhabitants $/ \mathrm{km}^{2}$. Both islands have significant mountainous terrain of 724-1000 m but also extensive coastal plains with beautiful beaches with clear waters suitable for swimming and other water-related activities. This combination makes these islands (also others in the region of Cyclades) as a very attractive tourism destination.

\section{Data analysis}

The analysis involves a two-step procedure. Initially we employed GIS software to superimpose critical elements directly impacted by sea level rise including surface elevations in relation to mean sea level and urban areas polygons adjacent to sea. Data were provided by the Hellenic Military Geographical Service and after applying interpolation techniques (Topo to Raster) elevation datasets were converted from polyline to raster format with a user-defined pixel size to $5 \mathrm{~m}$. Three different scenarios of sea level rise were developed illustrating the inundated areas after a sea level rise of $0.3 \mathrm{~m}$ (scenario 1), $0.6 \mathrm{~m}$ (scenario 2) and $1 \mathrm{~m}$ (Scenario 3) respectively. Basic statistics were computed for model results to determine total land area inundated at each different case. Geological formations were not taken into consideration as they will be considered at a future study. At the second phase of the analysis we estimated the economic impact resulting from sea level rise at each different scenario on islands. We calculated the economic loss according to the economic value of land and services at risk as they were been provided by Ministry of Finance and Economics Tables of land value. It is difficult to take account of the "sea-level rise" parameter in quantifying shoreline evolution. ${ }^{27}$ The most widespread method to achieve this aim is based on the Bruun rule. ${ }^{28}$ The methodology used herein was not based on the classical Bruun rule but the principle of active flooding which combines the relative sea level rise with the slope of the beach profile.

\section{Results and discussion}

A more complete understanding of the risks posed by climate change and the benefits of avoiding damages to coastal areas requires quantification and valuation of potential impacts. This is justified by the fact that there have been so far numerous approaches to estimate sea level rise levels. For example IPCC committee in their 2001 report estimate a sea level rise between 20 and $70 \mathrm{~cm}$ by 2100 while in the 2007 report they project a sea level rise by only $18-59 \mathrm{~cm}$ in the same period. At the same time, Rahmstoff et al. ${ }^{29}$ consider the IPCC estimates too conservative since they do not include in their model, the effect of the ice melting due to sea and air temperature increase, on the sea level rise process. ${ }^{30}$

In all cases, any information on the sea level rise estimates is valuable and can serve multiple purposes. First, valuation and incorporation of potential climate change impacts on coastal communities and ecosystems will help inform the design of climate change policy. Representation of these impacts in policy discussions may help reduce or minimize future costs, inform decisions to balance investments in mitigation and adaptation, and identify conditions that lead to the most dangerous and costly impacts. Second, land use planners responsible for protecting coastal development and natural systems will increasingly rely on information regarding resources and decisions that are most vulnerable or sensitive to climate change. In response to rising sea levels, coastal planners and homeowners are likely to protect their property by elevating structures, constructing seawalls, nourishing beaches, and using other methods. Such an investment in protecting shorelines will likely impose substantial costs on property owners, local municipalities, and state and federal programs. Modeling tools designed to estimate the value of resources at risk and the costs associated with protecting land from these impacts can help managers make decisions that promote sustainability, 
reduce overall costs, and improve coastal resiliency. While effective adaptation to the impacts of climate change can greatly reduce the eventual costs, it requires careful advance planning. ${ }^{31}$

The GIS approach is suitable for such purposes for two main reasons. First, a GIS-based approach is fast and can provide information within a very short time period. Second, a GIS system enables the mapping and visualization of the information and modeling results. At the same time, it provides access to numerous developed software add-ons for data analysis (statistics, biostatistics and spatial analysis) which are available for almost all GIS software in the market and which can provide more analytical information from the raw data (raster or vector). However the main limitation to our approach is the type of existent official elevation data from the Geographic Agency of the Greek Military. The Agency can provide elevation data for all Greek territory at minimum $4 \mathrm{~m}$ intervals. This combined with the fact that the sea level rise estimates range between $30 \mathrm{~cm}$ and $100 \mathrm{~cm}$, indicates that the digital elevation model which will be the basis of the analysis of the effects of sea level rise needs to be created by interpolation and therefore, a mathematical bias is entered in the results.

The basic results on land loss due to sea level rise are summarised in Table 1. Sea-level change is one of the observed consequences of global warming and future sea-level rise is inevitable in a warming world with the rates and geographical patterns of this rise remaining uncertain. ${ }^{5}$ Within coastal zones these climate-related changes can be expected to have a range of impacts. Rising sea levels will increase the flood-risk and erosion along the coast but may also impact freshwater availability or result in an accelerated loss of coastal eco-systems. A key element in assessing these issues is the development of sea-level rise scenarios (or plausible futures). Climate experts emphasize the importance of adapting to these potential effects of climate change by developing and implementing coastal protection and adaptation strategies. Coastal environment managers are increasingly concerned by the current rise in sea level and its possible acceleration during the $21^{\text {st }}$ century in relation to climate warming. ${ }^{24,25}$ This phenomenon coincides with an unprecedented socio-economic development of the coastal fringe. In coming decades on-going global warming will augment the probability of climate change. This may trigger alteration in sea level rise magnitude and rate as well as increase the impact of enhancing factors as shown in on-going global sea level rise as well as instances in sudden sea level rise situations over recent years. Human use of the coast increased dramatically in the last century and it seems that this trend will continue in the future. ${ }^{32}$

The most affected urban areas are located in the island of Naxos where land inundation ranges between 750 and 1100 thousand $\mathrm{m}^{2}$ with a respective cost between 890 million $€$ and 1.34 billion $€$. Paros is the second most inundated island among the Cyclades region (Table 2).

Coastal population growth in many low-lying areas has led to the conversion of natural coastal landscapes to land for agricultural aquaculture industrial and residential uses..$^{33}$ The attractiveness of the coast has resulted in rapid expansion of economic activity but has also degraded coastal ecosystems. Floods pose serious threats to coastal areas around the world; they cause great financial losses in property and infrastructure and affect many millions of people. ${ }^{32,34,35}$

Table 3 indicates that the island of Naxos have the highest economic loss from the inundation of non-urban areas due to sea level rise. Paros (with Antiparos) is located in the centre of Cyclades Island complex with 13715 and 1215 inhabitants in 2011. Both islands are among the most affected regions by sea level rise as the total economic loss ranges from 330 million $€$ (best case scenario) to 750 million $€$ (worst case scenario). Paros and Antiparos are highly visited islands with Antiparos to be a low-lying small island attracting high-income tourists and expensive tourism investments during the last years in contrast with Paros which is a traditional tourism destination mainly attracting mass tourism. Antiparos will lose $2.1 \%$ of the total island area after applying the second sea level rise scenario of $0.6 \mathrm{~m}$ while Paros is less affected with $0.8 \%$ land loss (Figure 2).

Table I Land loss per island and per scenario of sea level rise

\begin{tabular}{|c|c|c|c|c|c|c|}
\hline \multirow{2}{*}{ Island } & \multicolumn{3}{|c|}{ Total lostarea $\left(\mathbf{m}^{2}\right)$} & \multicolumn{3}{|c|}{ Percentage of islandarea (\%) } \\
\hline & $0.3 \mathrm{~m}$ & $0.6 \mathrm{~m}$ & Im & $0.3 \mathrm{~m}$ & $0.6 \mathrm{~m}$ & Im \\
\hline Naxos & 3755518 & 4573025 & $553185 \mid$ & 0.87 & 1.06 & 1.28 \\
\hline Paros(with Antiparos) & 1540388 & $2457 \mid 48$ & 3501314 & 0.94 & 1.49 & 2.12 \\
\hline
\end{tabular}

Table 2 Area and corresponding economic value of the losses for Naxos and Paros islands due to inundation of urban areas

\begin{tabular}{|c|c|c|c|c|c|c|}
\hline & \multicolumn{3}{|c|}{ Lost urban area $\left(\mathrm{m}^{2}\right)$} & \multicolumn{3}{|l|}{ Value $(€)$} \\
\hline & $0.3 \mathrm{~m}$ & $0.6 \mathrm{~m}$ & Im & $0.3 \mathrm{~m}$ & $0.6 \mathrm{~m}$ & $\mathrm{Im}$ \\
\hline Naxos & 751104 & 914605 & 1106370 & $892588985 €$ & $|086889| 44 €$ & $134|777| 55 €$ \\
\hline Paros(with Antiparos) & 308078 & 491430 & 700263 & $322763659 €$ & $514856049 €$ & $733644328 €$ \\
\hline
\end{tabular}

Table 3 Area and corresponding economic value of the losses for Naxos and Paros islands due to inundation of non-urban area

\begin{tabular}{|c|c|c|c|c|c|c|}
\hline & \multicolumn{3}{|c|}{ Lost non-urban-area $\left(\mathrm{m}^{2}\right)$} & \multicolumn{3}{|l|}{ Value $(€)$} \\
\hline & $0.3 \mathrm{~m}$ & $0.6 \mathrm{~m}$ & Im & $0.3 \mathrm{~m}$ & $0.6 \mathrm{~m}$ & Im \\
\hline Naxos & $30044 \mid 4$ & 3658420 & 4425481 & $165 \mid 5867 €$ & $20111066 €$ & $24327753 €$ \\
\hline Paros(with Antiparos) & 1232310 & 1965718 & 2801051 & $7080363 €$ & I I $294232 €$ & $16093720 €$ \\
\hline
\end{tabular}

Naxos is a large island with 20837 (2011) inhabitants with imposing mountainous volumes and strong winds. The topography of the island is a representative example of the Aegean topography characterized by hills and mountains covered by bushes and very limited flat fields. It is considered as the most fertile island of Cyclades. Naxos is the most vulnerable island relative to the others; since it risks losing a higher percentage of land (1.06\%) for sea level rise of $0.60 \mathrm{~m}$ (Figure
3). Moreover it faces the most severe economic cost as for the most possible scenario of sea level rise $0.6 \mathrm{~m}$ the economic cost accounts for 1.1 billion€. Based on the above measurements Klidos is the most hazardous urban area as $15.54 \%$ of the land is inundated. The western part of Naxos is susceptible to future sea level rise and especially the southern part of Naxos capital. 


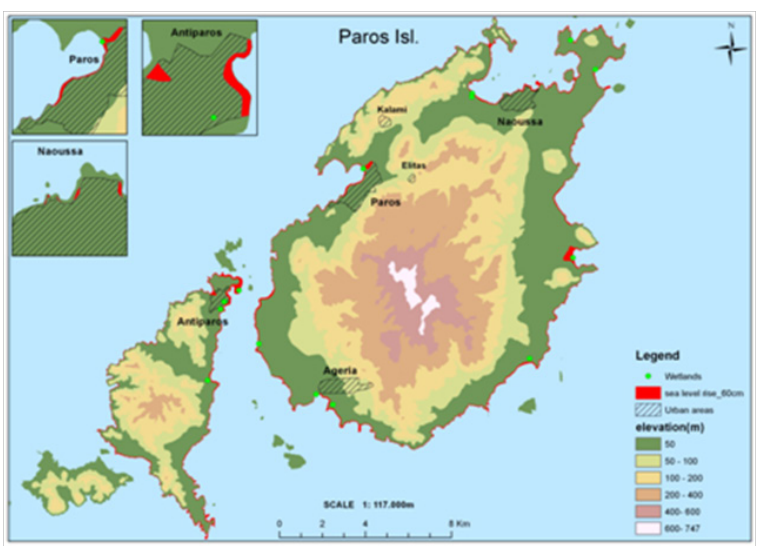

Figure 2 Land losses (red) for the second sea level rise scenario of $0.6 \mathrm{~m}$ for Paros and Antiparos Islands.

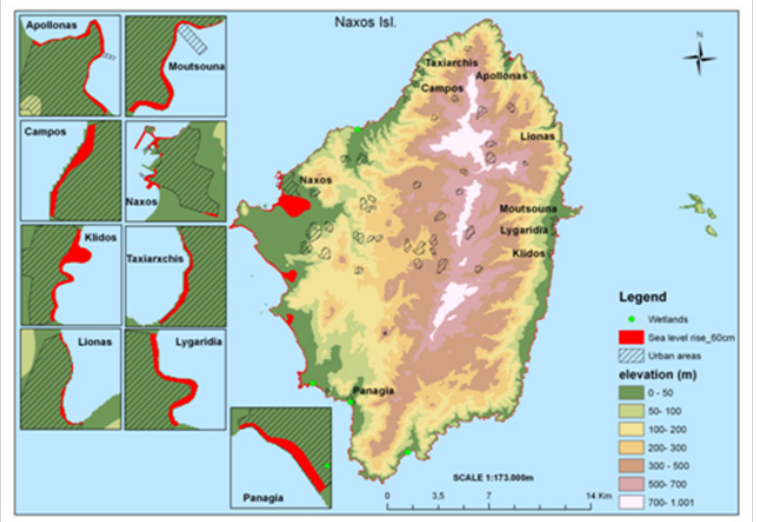

Figure 3 Land losses (red) for the second sea level rise scenario of $0.6 \mathrm{~m}$ for Naxos Island.

Possible impacts of climate change on Greek coastal areas are far reaching given the geomorphology of the country and the high percentage of population living in these areas. As in any coastal management decision, socioeconomic and ecological considerations need to be taken into account before selecting a possible approach.

\section{Conclusion}

Regarding the effects of sea level rise in Cyclades region, the estimated land loss from the inundation due to sea level rise is larger in low-lying areas highly prevalent in the island of Paros-Antiparos. The economic loss from the inundation of urban areas of the Cyclades Island Complex due to sea level rise is highest in the island of Naxos. In order policy makers to take appropriate action where and when need to be, it is important to grasp the specific vulnerability at the local level to each of the different climate change threats. Nevertheless, current scientific research results are not always supportive enough to develop climate adaptation strategies and coastal protection plans and decide on the optimal adaptation measures. Even in countries more advanced in climate change research, the uncertainties with respect to meteorological changes cause severe discrepancies between estimates given by different institutions and thus hamper accurate policy development.

\section{Acknowledgements}

Data analysis and collection information for this paper was carried out within the research project PEGASO: People for Ecosystem- based Governance in Assessing Sustainable development of Ocean and coast, FP7 Collaborative Projects-Large scale integrating project, funded by EU DG-Research under the contract number 244170 (2010-2014)

\section{Conflicts of interest}

None.

\section{References}

1. Melloul A, Collin M. Key natural and anthropogenic parameters enhancing the effect of sea level rise: The case of Israel's Mediterranean coast. Ocean \& Coastal Management. 2009;52(1):39-46.

2. Field CB, Mortsch LD, Brklacich M, et al. North America. In: Parry ML, et al. (Eds), Climate Change 2007: Impacts, Adaptation and Vulnerability. Contribution of Working Group II to the Fourth Assessment Report of the Intergovernmental Panel on Climate Change. Cambridge University Press, Cambridge, UK. 2007. pp.617-652.

3. CCSP. Coastal Sensitivity to Sea-Level Rise: A Focus on the MidAtlantic Region A report by the U.S. Climate Change Science Program and the Subcommittee on Global Change Research. US Environmental Protection Agency, Washington, DC, USA. 2009.

4. Karl TR, Melillo JM, Peterson TC. Global climate change impacts in the United States. Cambridge: Cambridge University Press. 2009.

5. IPCC. Climate Change 2007: impacts, adaptation and vulnerability. Contribution of working group II to the fourth assessment report of the intergovernmental panel on climate change. Cambridge University Press, Cambridge, UK, pp.976. 2007.

6. Church JA, White NJ. A $20^{\text {th }}$ century acceleration in global sea level rise. Geophysical Research Letters. 2006;33(1):1-4.

7. Lambeck K, Anzidei M, Antonioli F, et al. Sea level in Roman time in the Central Mediterranean and implications for recent change. Earth and Planetary Science Letters. 2004;224:563-575.

8. Nicholls RJ Small C. Improved estimates of coastal population exposure to hazards released. EOS Transactions. 2002;83(28):303-305.

9. IOC/UNESCO, IMO, FAO, UNDP. A Blueprint for Ocean and Coastal Sustainability. IOC/UNESCO, Paris. 2011.

10. Nicholls RJ, Tol RSJ. Impacts and responses to sea-level rise: A global analysis of the SRES scenarios over the twenty-first century, Philosophical Transactions of the Royal Society A. 2006;364:1073.

11. Marbaix P, Nicholls RJ. Accurately determining the risks of rising sea level, EOS Transactions. 2007;88(43):441-442.

12. Travers A, Elrick C, Kay R. Background Paper: Climate Change in Coastal Zones of the Mediterranean. Priority Actions Programme, Mediterranean Regional Activity Centre, Coastal Zone Management Pty Ltd, Claremont, Australia. 2010.

13. European Commission. Sustainability Report. Luxemburg: Office for Official Publications of the European Communities. 2009;pp.160.

14. Carillo A, Sannino G, Artale V, et al. Steric sea level rise over the Mediterranean Sea: present climate and scenario simulations. Climate Dynamics. 2012;39(9/10):2167-2184.

15. Tsimplis MN, Marcos M, Colin J, et al. Sea level variability in the Mediterranean Sea during the 1990s on the basis of two 2D and one 3d model. Journal of Marine Systems. 2009;78(1):109-123.

16. Tsimplis MN, Baker TF. Sea level drop in the Mediterranean Sea: An indicator of deepwater salinity and temperature changes? Geophysical Research Letters. 2000;27(12):1731-1734. 
17. Paulopoulos K, Chalkias C, Karimbalis E. Potential impact of sea level rise on Mykonos, Delos, Rinia islands, In: 6th Pan-Hellenic Geographical Conference, Thessaloniki. 2002;pp.3:469-476.

18. EUROSTAT. Coastal regions. In: Asa Onnerfors (Ed.), Eurostat regional yearbook 2011. Luxembourg: Publications Office of the European Union, Belgium. 2011.

19. Coudert E, Larid M. IMAGINE: un ensemble de méthodes et d'outils pour contribuer à la gestion intégrée des zones côtières en Méditerranée, Vertigo-la revue électronique en sciences de l'environnement, Dossier : Les littoraux et la gestion intégrée des zones côtières. 2006;7(3).

20. Devoy RJN. Coastal Vulnerability and the Implications of Sea-Level Rise for Ireland. Journal of Coastal Research. 2008;24(2):325-341.

21. Barth MC, Titus JG. Greenhouse effect and sea level rise: A challenge for this generation, Van Nostrand Reinhold, New York, USA. 1984;pp.324.

22. Milliman JD, Broadus JM, Gable F. Environmental and economic implications of rising sea level and subsiding deltas: The Nile and Bengal examples. Ambio. 1989;18(6):340-345.

23. Warrick RA, Barrow EM, Wigley TML. Climate and sea level change: Observations, projections, implications. Cambridge University Press, Cambridge. 1993.

24. IPCC. Climate change 2001: impacts, adaptation and vulnerability Contribution of the working group to the 3rd assessment report of the intergovernmental Panel on Climate Change. World Meteorological Organization, Geneva. 2001;pp.124.

25. IPCC. Climate change 2001: impacts, adaptations and vulnerability. In: McCarthy JJ, et al. (Eds.), Contribution of Working Group II to the Third Assessment Report of the Intergovernmental Panel on Climate Change. Cambridge University Press, Cambridge. 2001;p.75.
26. National statistical Survey of Greece. Population, housing and buildings Census 2001. 2003;p.18

27. Dubois RN. How does a barrier shoreface respond to a sea-level rise? Journal of Coastal Research. 2002;18:2.

28. Bruun P. Sea-level rise as a cause of shore erosion. Journal of Waterways and Harbors Division. 1962;117-130.

29. Rahmstorf S, Foster G, Cazenave A. Comparing climate projections to observations up to 2011. Environmental Research Letters. 2012;7:4

30. Al-Buloshi A, Al-Hatrushi S, Charabi Y. GIS-based Framework for the Simulation of the Impacts of Sea Level Rise and Coastal Flooding on Oman. Journal of Earth Science \& Climatic Change. 2014;5(10):1-6.

31. Neumann JE, Hudgens DE, Herter J, et al. Assessing Sea-Level Rise Impacts: A GIS-Based Framework and Application to Coastal New Jersey. Coastal Management. 2010;38(4):433-455.

32. Nicholls RJ, Tol RSJ, Vafeidis AT. Global estimates of the impact of a collapse of the West Antarctic ice sheet: an application of FUND. Climatic Changes. 2008;91(1-2):171-191.

33. Valiela I. Global coastal change. Wiley-Blackwell, London. 2006;pp.376.

34. Dasgupta S, Laplante B, Meisner C, et al. The impact of sea level rise on developing countries: a comparative analysis. Climatic Change. 2009;93(3-4):379-388.

35. Nicholls RJ. Coastal flooding and wetland loss in the $21^{\text {st }}$ century: changes under the SRES climate and socio-economic scenarios. Global Environmental Changes. 2004;14(1):69-86. 